\title{
THE EFFECTIVENESS OF GOOGLE CLASSROOM IN TEACHING WRITING OF RECOUNT TEXT FOR SENIOR HIGH SCHOOLS
}

\author{
${ }^{1}$ Ela Nur Laili, ${ }^{2}$ Tatik Muflihah \\ ${ }^{1}$ Student, English Department, Universitas Nahdlatul Ulama Surabaya, Indonesia \\ ${ }^{2}$ English Lecturer, English Department, Universitas Nahdlatul Ulama Surabaya, Indonesia \\ Corresponding Author Email: elalaili23@gmail.com; miraicha@unusa.ac.id
}

\begin{tabular}{|c|c|}
\hline Article Info & Abstract \\
\hline $\begin{array}{l}\text { Article History } \\
\text { Received: September } 2020 \\
\text { Revised: September } 2020 \\
\text { Published: October } 2020\end{array}$ & $\begin{array}{l}\text { This research aimed to find out Google Classroom effectiveness, which was used to } \\
\text { enhance students' writing recount text for Senior High School and recognize } \\
\text { students' writing performance. This research used a pre-experimental research } \\
\text { design. The subject of this study is the tenth grade of senior high school at }\end{array}$ \\
\hline $\begin{array}{l}\text { Keywords } \\
\text { Google Classroom; } \\
\text { Writing; } \\
\text { Recount Text; }\end{array}$ & $\begin{array}{l}\text { Western Surabaya. It involved } 30 \text { students as a sample of this study. In the process } \\
\text { of data collection, the researcher used a pre-test, post-test, and questionnaire. The } \\
\text { researcher analyzed the data using Wilcoxon Ranks Test to test the hypothesis. This } \\
\text { study found the value of significance (2-tailed) was lower than the significance } \\
\text { level (0.022 < 0.05), then the Ha was accepted. It means there was a significant } \\
\text { value on students' achievement of the writing performance of recount text by using } \\
\text { Google Classroom. In addition, the result of the questionnaire indicates that the } \\
\text { students' responses are neutral; it means that the students do not feel difficult in } \\
\text { the use of Google Classroom. However, it can be concluded that Google } \\
\text { Classroom significantly affects students' writing performance and helps them finish } \\
\text { and collect the assignment without any bound by time and space. Further, based on } \\
\text { the data obtained, which analyzed through Brown's theory, the students' writing } \\
\text { performance is imitative and intensive. It means they are still positioning in the } \\
\text { primary category. }\end{array}$ \\
\hline
\end{tabular}

How to cite: Laili, E. N. \& Muflihah, T. (2020). The effectiveness of google classroom in teaching writing of recount text for senior high school. JOLLT Journal of Languages and Language Teaching. 8(4), 348-359, DOI: https://doi.org/10.33394/jollt.v\%vi\%i.2929

\section{INTRODUCTION}

Nowadays, the development of technology influences all human life to do anything in their daily activities. The world today has been getting into the new era called industry 4.0, in which all things are conducted by people using digital technology (Kerzik et al., 2018). The digital industry's development has empowered all people to think globally and act locally, which must be able and ready to be part of it. This embodiment can impact the transformation in any fields or sectors of human life, including education.

There are many embodiments of technology that can be applied in the education sector, such as Google Classroom, Zoom Cloud Meeting, and Duo lingo (Genova, 2019). Those are online applications that help teachers and students in learning. Google Classroom is an online application promoted by Google for schools intended to facilitate teachers in assorting, creating, and valuing the task in a paperless way (Negara, 2018). Zoom Cloud Meeting is a perfect tool for those who are on the way and still need to have a meeting. It has a special group service of massages in the real-time and secure recording sessions (Archibald, Ambagtsheer, Casey, \& Lawless, 2019). Duo lingo is a useful language application that gives learners the systematic and practical steps to know a new language independently.

The use of Google Classroom is the point of the discussion in the education issues. It is an online device generated to help teachers and students in conducting the teaching and learning process. The initial release of Google Classroom is on August 12, 2014. Negara 
(2018) explains that Google Classroom is an application to help teachers or lecturers create, share, collect paperless assignments, and assess student assignments complemented by automatic document storage. It can also be utilized as a medium of interaction between students and teachers, organizing classes while in distance class or paperless tasks can be held without being bound by space and field. The learning and teaching process is organized and conducted through the Google platform, which is integrated with an email. Each student is demanded to possess one email account to participate in online learning.

The existence of Google Classroom as an instructional medium is a new thing in the education sector, which is expected to make the learning and teaching process easier, especially in teaching recount text. The use of Google classroom is oriented to make students comfortable learning and teaching processes without any inserted assignment during the class. Writing defines one of the productive skills that is also known as the most difficult skill among other skills (Haerazi et al., 2020). This is caused by complex writing activities such as; organize the ideas or information, avoiding ambiguity, making grammatical use, and choosing an appropriate vocabulary. This is in line with what was explained McLean (2011) that effective writing involves the organization in developing ideas, argumentation, and information, a great exactness to keep away from ambiguity, an intricacy of grammatical use, and selecting an appropriate vocabulary.

Based on the pre-observation in Senior High School X, the writer found that problems commonly face students' writing as following; they feel hard to obtain an idea to write because they dislike reading. Another thing that may contribute to the difficulty is to compose writing because of a lack of vocabulary. Next, they frequently get confused about constructing sentences with correct grammar. The last, the teacher used a monotonous method. As a result, students quickly get bored.

Dealing with the emergence of problems, the researcher prefers to include Google Classroom as the instructional medium in teaching writing recount text used outside of the classroom. It is intended to make students feel free and make them acquire critical thinking skills and fresh ideas. In addition, it can provide them with much more inspiration to finish their assignments. The insertion is the involvement of Information and Communication (ICT) development in the teaching and learning process among students and the teachers without any bound by time and space. Therefore, this study aims to open up a broad knowledge of the Google Classroom that affects teaching writing in the EFL Classroom. In the light of the theoretical background, the following statement of the problems leads the current research are: What is the effectiveness of Google Classroom in teaching writing recount text? What is the writing performance achieved by students? This study was underpinned by some theoretical bases in using online learning and learning tools.

\section{Writing}

Writing is a productive skill that focuses on how to produce language than receive it. Harmer (2012) found that writing is a continuing activity that comes from the writer's mind about what they want to say and how to say it. The writer should read and correct their writing after finished writing the text. Therefore, writing needs one step, but it needs several steps: planning, drafting, editing, and final version (Harmer, 2012). However, good writing commonly attracts a reader to pay attention to the text. So the students need to use correct grammatical rules, choose suitable vocabularies, and consider the coherent and cohesion, then it will afford good sentences with exact meaning (Wijaya, 2014).

The teacher should understand how to teach four skills in the English language, especially in teaching writing. Kurotun (2015) explained that there are many reasons to teach writing to students, such as; 1) Reinforcement is the process of acquiring language by students in a purely oral/aural way. 2) Language development is the process of how students 
arrange their writing. When they are writing, they create the text to be an explorer with the language. 3) Learning style is possible to discover an easier way to acquire language by looking and listening. Writing is appropriate for students because it makes them think things slowly in producing speech. 4) Writing is a skill. It is crucial as other skills. Students need to understand how to write emails, letters, and reports.

\section{Recount Text}

A recount text is a text that retells something happen in past events; usually, the writer retells their experiences or events that happen in the past. A recount text is similar to a narrative text. It has not any complication part, whereas narrative text. This is in line with what was assumed by Wisdhawan and Kumalarini (2014) that recount text is a text which retells everything happens in the past events. It can be conducted with experiences and activities that happened in the past. It has three types; the first, personal recount the example, diary, and personal letters/email. The second is factual retelling such as scientific research and newspaper report; the third is an imaginative recount.

\section{Google Classroom}

Google Classroom is considered one of Google's web's best features for improving teachers' and students' performance in teaching and learning activities. It is included as a set of useful features to make it an ideal device that can be used by the scholar. It can save many times and still keep the class is on. Iftakhar (2016) explained that Google Classroom is the best feature provided by the Google platform that can be used by the scholar to get information about the class material with the use of many times saved. It can be accessed by everyone on their smartphone, tablet, laptop, and personal computer. It is available for every electronic with Google Application for education, free installation of productivity devices, including Gmail, Drive, and Documents.

Google Classroom is completely simple to be used. Here are all available features integrated and correlated between one and others. The teachers facilitated to keep all files in Google Drive. Using this device, they can give rank and level, attach pdf, photo, video, voice note, document, or any links for instructional purposes. From Google Classroom, the teacher can send the assignment to all learners' at the same time (Iftakhar, 2016).

The other things that may contribute to the advantage of Google Classroom are spending time more saved. Next, the teachers can give the class instructions and share the paperless assignment, comment, and scoring of students' work simultaneously. Then it can minimize wasting time when the class is on. Furthermore, the teachers were more focused on explaining the material during the class (Iftakhar, 2016).

Google Classroom has many advantages, but it also has disadvantages even if it is equipped with good features. The disadvantages include limited integrated options to Google Calendar, which may help handle assignment deadlines and material by the time decided. When Google Classroom is integrated into Google Calendar, the students currently get notifications of every assignment equipped with their phones' alarm. (Pappas, 2015).

\section{Previous Studies: Google Classroom in EFL}

In the previous study, Negara (2018) conducted her research used quantitative with a descriptive approach, and it was carried out in the English Literature Study Program, STBA Pontianak. The subject was seventh-semester students of STBA Pontianak. The data collection was using a questionnaire by distributing a set of written statements to the respondents to be answered. The questionnaire consists of statements using the assessment criteria in the shape of a scale shared into a scale of 1 to 4 , such as; strongly agree, disagree, agree, strongly agree. The indicators of the effectiveness of Google Classroom as teaching 
media include usefulness, ease of use, and satisfaction. The findings were described using descriptive statistics. The average students showed a positive response. The result of the usefulness indicator showed that the highest score was $(88.51 \%)$, the middle score was $(80.37 \%)$, and the lowest score was $(70 \%)$. The result of Google Classroom about ease of use indicator showed that the highest score was $(91.85 \%)$, the middle score was $(91.48 \%)$, and the lowest score was $(77.4 \%)$. The result of satisfaction indicated that the highest score was $(92.60 \%)$, the middle score was $(91.11 \%)$, and the lowest score was $(87.40 \%)$. It can be inferred that respondents strongly agree that Google Classroom is very worthwhile in learning activities.

Alim conducted the research that focuses on the same field Their research used descriptive qualitative through interview segments with students from the faculty of teacher training and education at the Islamic State Institute of Kendari (IAIN Kendari). The interview was carried out with the students' focus. The results of this study depict that the use of Google Classroom is effective. However, there were limitations seen during its implementation. For example, some students do not obtain an account because they do not have a mobile phone. In addition, the accessible Wi-Fi in the college is limited, and the students do not have enough network data during the online conference, and even some students turned in their duty using their friends' accounts.

The next researcher who conducts in the same field was Harjanto and Sumarni (2019), which reveals the teacher's perspective on the use of Google Classroom as a learning media. This study was qualitative research through the interview method. It was involved seven high school teachers who have actively implemented Google Classroom in their teaching at least 1 year. This study showed that the teachers apply it as a facilitation tool for organizing students' tasks, managing the classroom, and facilitating student interaction. It was also very helpful to carry out their virtual learning.

\section{RESEARCH METHOD}

This study was a quantitative research with a specific design, namely pre-experimental research. The researcher is concerned with one case that currently exists in the field of education. The design of this study used a one-group pretest-posttest. This research conducted one experimental group without any control group. It was the weakness of pre-experimental research because of the lack of a comparative group to control for incompatible variables that might contaminate the result of the study (Latief, 2015).

Here are the steps of the research. First, the researcher prepared the instrument. Then the researcher used teachers' journals as a pre-test to measure students' writing knowledge. Secondly, she was given treatment to determine the effectiveness of using Google Classroom in writing recount text performance. After giving the treatment, she was providing the posttest that related to the recount-text. This was conducted to know the students' achievement after the group is treated. The last step was giving a questionnaire to the learners' to collect the data in-depth about the effectiveness of using Google Classroom to support the data collection.

\section{Population and Sample}

This study's population was tenth-grade students of SMA in the West Surabaya, in the academic year of 2019-2020 that consists of 5 classes such as X IPA 1, X IPA 2, X IPA 3, X IPS 1, and X IPS 2. Every class consists of 30 students except IPS 2 that consists of 28 students. Then, the total population is about 148 students. However, they have the same chance to be the object of this study. 
The researcher's obtained result bases the researcher to choose one class that undertook difficulties in writing. They need some treatments in the learning process, namely XIPS 1 that consists of 30 students. The total sample of this study was 30 students.

\section{Instrument}

In this study, the data collection techniques were test and questionnaire. The purpose of the test was to obtain the data of students' writing performance in teaching writing recount text with Google Classroom as the instructional medium which is distributed to them after giving the treatment. The purpose of the questionnaire was to obtain the data in-depth about the use of Google Classroom as the instructional medium in teaching writing recount text. It consist of 10 questions with a closed answer. The questionnaire which was given to students is related to the platform's performance during the implementation of the teaching and learning process. It aims to figure out the students' respond with the use of Google Classroom.

The researcher handed over the students with a post-test after giving treatment. Here was the treatment; Firstly, the researcher introduced Google Classroom to the students and asked them to join the classroom created by the researcher, then the researcher conducted brainstorming about students understanding of recount text. After that, the researcher explained the recount text and gave them an example of it. Next, she gave some questions related to the example given to guide students in writing recount text, and she asked them to construct a recount text by using their real experiences orally. By the end of the session, the researcher asked students to make a conclusion together according to the topic. Finally, she asked students to pay attention to Google Classroom because the assignment and the material were delivered through it.

Dealing with the spreading of pandemic covid-19, the government policy demands all the human activity, including education field to be conducted through online classroom (long distance learning). The researcher then replaced the pre-test distribution with the teacher's journal in term of students' writing score. The post-test given to the students was in the form of an essay. It was delivered in Google Classroom by the following instruction; write one of the following topics such as; historical event, folk tale, a legend, or personal experience which consist at least three paragraph and 200 words by notes or word application then resend it to the teacher through Google Classroom. After finishing the post-test, students were requested to fulfill the questionnaire to support data of the research.

\section{Data Analysis}

This study used Paired-Sample T-Test as a data analysis technique, and the data was analyzed using IBM SPSS Statistics 23. This test aimed to determine whether there are differences between the result of pre-test and post-test of students' scores.

\section{Validity and Reliability}

In this study, the researcher tested the validity of students' essays of recount text and a questionnaire was chosen as the instrument's validity. It was a test with a score in the form of a continuum. Djaali and Muljono (2014) explained that if the item score is a continuum, then to test the validity of the item test by calculating the product-moment correlation coefficient between the item score and the total score.

Jonhson and Christensen (2016) explained that reliability shows the stability or consistency of the test scores. In this study, the researcher preferred to use Alpha Cronbach method. It is a reliability test continuum with a range score of $0-10$ or $0-100$. 


\section{Normality Test}

Ananda and Fadhli (2018) explained that the normality test is purposed to point out whether the data distribution is normal or not. This was important to be recognized, dealing with the provision of parametric statistical test selection requiring data to be normally distributed. The researcher used SPSS to measure the normality test of pre-test and post-test of students' scores, namely One Sample Kolmogorov-Smirnov Test and Shapiro-Wilk. The basic formula is if the significance value is higher than 0.05 then the data have a normal distribution. On the contrary, if the significance value is less than 0.05 then the data is not normal.

\section{RESEARCH FINDINGS AND DISCUSSION}

The following section points out the research findings and discussion. Some data are presented for research findings such as data description, validity, reliability, data analysis, hypothesis testing, and discussion.

\section{Research Findings \\ Data Description}

The data description is presented three kinds of data; the score of pre-test, post-test, and the result of the questionnaire. The test was analyzed using a writing scoring rubric.

Table 1

Pre-test and Post-test Scores

\begin{tabular}{lrrr}
\hline \multicolumn{4}{c}{ Statistics } \\
\hline \multirow{4}{*}{$\mathrm{N}$} & Pre-test & Posttest \\
\cline { 2 - 4 } & Valid & 30 & 30 \\
\cline { 2 - 4 } Mean & 0 & 0 \\
\hline Median & 77.77 & 51.63 \\
\hline Std. Deviation & 79.00 & 75.00 \\
\hline Minimum & 15.199 & 40.355 \\
\hline Maximum & 0 & 0 \\
\hline
\end{tabular}

Table 1 displayed the students' pre-test with the highest score was 90, and the lowest was 0 . While the students' post-test with the highest score was 92, and the lowest was 0. After gained the students' scores, the data were analyzed using IBM SPSS Statistic 23. Table 2 presents the result frequency score in the pre-test.

\section{Table 2}

Frequency score in the pre-test

\begin{tabular}{cccccc}
\hline \multirow{7}{*}{ Valid } & Frequency & Percent & $\begin{array}{c}\text { Valid } \\
\text { Percent }\end{array}$ & $\begin{array}{c}\text { Cumulative } \\
\text { Percent }\end{array}$ \\
\cline { 2 - 6 } & 0 & 1 & 3.3 & 3.3 & 3.3 \\
\cline { 2 - 6 } & 76 & 4 & 13.3 & 13.3 & 16.7 \\
\cline { 2 - 6 } & 17 & 3.3 & 3.3 & 20.0 \\
\hline 78 & 9 & 30.0 & 30.0 & 50.0 \\
\hline 80 & 6 & 20.0 & 20.0 & 70.0 \\
\hline 82 & 2 & 6.7 & 6.7 & 76.7 \\
\hline 84 & 2 & 6.7 & 6.7 & 83.3 \\
\hline 86 & 2 & 6.7 & 6.7 & 90.0 \\
\hline 88 & 2 & 6.7 & 6.7 & 96.7 \\
\hline 90 & 1 & 3.3 & 3.3 & 100.0 \\
\hline
\end{tabular}


From Table 2, it can be seen that one student has a score 0 ; four students have a score 76 , which indicates that several students experienced an obstacle in the process of writing performance. They are difficult to construct sentences into paragraphs, caused by the lack of concepts or ideas. In addition, 25 students received scores of 77, 78, 80, 82, 84, 86, 88, and 90 that indicates that they did not get any serious problem in writing performance. Table 3 presents the result statistic and frequency score in the post-test.

Table 3

Frequency of Score in Post-test

Posttest

\begin{tabular}{|c|c|c|c|c|c|}
\hline & & Frequency & Percent & Valid Percent & $\begin{array}{c}\text { Cumulative } \\
\text { Percent }\end{array}$ \\
\hline \multirow[t]{6}{*}{ Valid } & 0 & 11 & 36.7 & 36.7 & 36.7 \\
\hline & 67 & 1 & 3.3 & 3.3 & 40.0 \\
\hline & 75 & 6 & 20.0 & 20.0 & 60.0 \\
\hline & 83 & 8 & 26.7 & 26.7 & 86.7 \\
\hline & 92 & 4 & 13.3 & 13.3 & 100.0 \\
\hline & Total & 30 & 100.0 & 100.0 & \\
\hline
\end{tabular}

From the table above, 1 student has score 67,6 students have score 75 , and 8 students have score 83 , and 4 students have score 92 . This can be seen that 11 students did not collect their assignment as a result the researcher gave them 0 score.

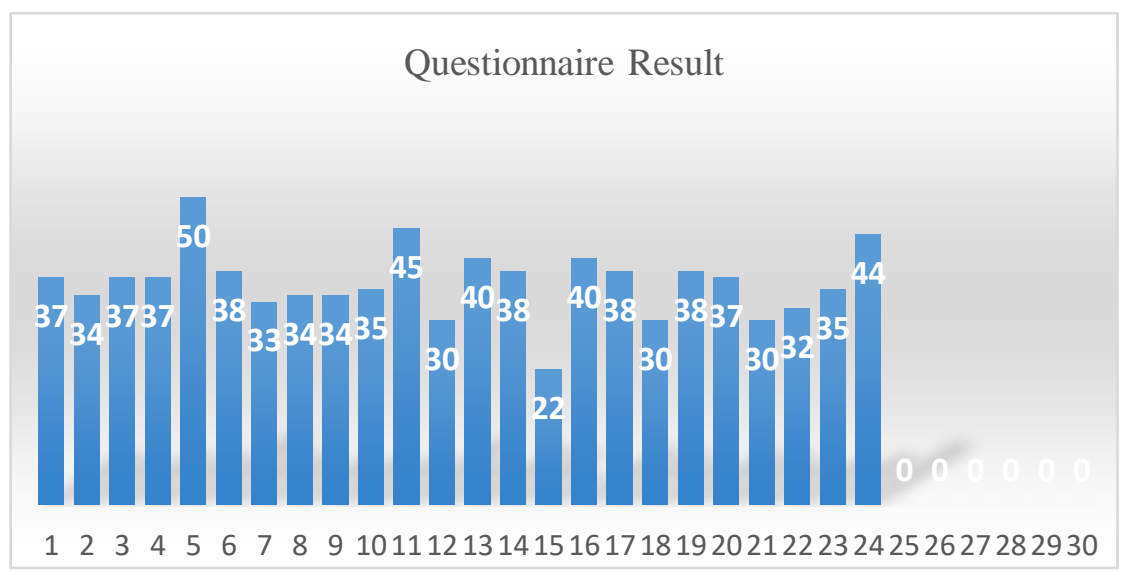

Figure 1. Questionnaire Result

Based on the findings in the preceding chart, it showed students' responses about the implementation of Google Classroom as a teaching and learning medium. The researcher counted the number of students' responses is positioning average, which means they respond neutral. On the other hand, several students did not turn in their questionnaire, but it did not affect the whole data. Then the total response of this questionnaire data is 24 students. It can be inferred that students behave fairly balanced in responding to the implementation of Google Classroom. It means they did not experience any difficulties in using Google Classroom as a medium in teaching recount text.

\section{Validity and Reliability}

To analyze the students' essay writing recount text's validity, the researcher applied the validity test of Product Moment through IBM SPSS Statistics 23. If the significance value (2tailed) $<0.05$ and Pearson correlation has a positive value, it indicates the question is valid. Whereas, if the significance value (2-tailed) $>0.05$ and Pearson correlation has a negative value, it indicates the question is not valid. The result can be seen in Table 4 below: 
Table 4

Validity Result

\begin{tabular}{|c|c|c|c|c|c|}
\hline \multicolumn{6}{|c|}{ Correlations } \\
\hline & & Item_1 & Item_2 & Item_3 & Skor_total \\
\hline \multirow[t]{3}{*}{ Item_1 } & Pearson Correlation & 1 & $.955^{* *}$ & $.938^{* * *}$ & $.981^{* *}$ \\
\hline & Sig. (2-tailed) & & .000 & .000 & .000 \\
\hline & $\mathrm{N}$ & 30 & 30 & 30 & 30 \\
\hline \multirow[t]{3}{*}{ Item_2 } & Pearson Correlation & $.955^{* *}$ & 1 & $.974^{* *}$ & $.991^{* *}$ \\
\hline & Sig. (2-tailed) & .000 & & .000 & .000 \\
\hline & $\mathrm{N}$ & 30 & 30 & 30 & 30 \\
\hline \multirow[t]{3}{*}{ Item_3 } & Pearson Correlation & $.938^{* * *}$ & $.974^{* *}$ & 1 & $.984^{* *}$ \\
\hline & Sig. (2-tailed) & .000 & .000 & & .000 \\
\hline & $\mathrm{N}$ & 30 & 30 & 30 & 30 \\
\hline \multirow[t]{3}{*}{ Skor_total } & Pearson Correlation & $.981^{* *}$ & $.991^{* * *}$ & $.984^{* *}$ & 1 \\
\hline & Sig. (2-tailed) & .000 & .000 & .000 & \\
\hline & $\mathrm{N}$ & 30 & 30 & 30 & 30 \\
\hline
\end{tabular}

**. Correlation is significant at the 0.01 level (2-tailed).

From the preceding table, $\mathrm{N}=30$ means there are 30 samples of the research. The total score of significance (2-tailed) for item 1, 2, and 3 was 0.000 . It indicates that the questions are valid. In accordance to the formula, if the significance value $<0.05$ it means the question is valid whereas, if the significance value $>0.05$, it indicates the question is not valid.

To analyze the test's reliability, the researcher used the reliability test of Alpha Cronbach method through IBM SPSS Statistics 23. The basis for decisions in Alpha Cronbach reliability testing is: If the value of Alpha Cronbach $>0.60$ it indicates the question or questionnaire is reliable. Whereas, if the value of Alpha Cronbach $<0.60$ it indicates the question or questionnaire is not reliable. The result of reliability test can be seen in Table 5 .

Table 5

Reliability of Test

\begin{tabular}{llrr}
\multicolumn{4}{c}{ Case Processing Summary } \\
\hline \multirow{3}{*}{ Cases } & \multicolumn{1}{l}{$\mathrm{N}$} & $\%$ \\
\cline { 2 - 4 } & Valid $^{\text {Excluded }}{ }^{\mathrm{a}}$ & 30 & 100.0 \\
\cline { 2 - 4 } & Total $^{2}$ & 0 & .0 \\
\hline
\end{tabular}

a. Listwise deletion based on all variables in the procedure.

Reliability Statistics

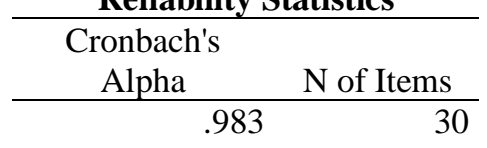

The table above shows that the total score of the reliability test was $0.983>0.60$, indicating that the test was reliable. To analyze the questionnaire's validity, the researcher applied the Product Moment using IBM SPSS Statistics 23. If the significance value (2-tailed) $<0.05$ and Pearson correlation has a positive value, it indicates the questionnaire is valid. Whereas, if the significance value (2-tailed) $>0.05$ and Pearson correlation has a negative value, it indicates the questionnaire is not valid. The result can be seen in Table 6 . 
Table 6

The validity of Questionnaire Result

\begin{tabular}{ccccc} 
Question & $\boldsymbol{r}_{\boldsymbol{x y}}$ & Sig. (2-tailed) & $\boldsymbol{r}_{\text {tabel }}$ & Status \\
\hline Q1 & 0.893 & 0.000 & 0.361 & Valid \\
\hline Q2 & 0.951 & 0.000 & 0.361 & Valid \\
\hline Q3 & 0.917 & 0.000 & 0.361 & Valid \\
\hline Q4 & 0.851 & 0.000 & 0.361 & Valid \\
\hline Q5 & 0.930 & 0.000 & 0.361 & Valid \\
\hline Q6 & 0.931 & 0.000 & 0.361 & Valid \\
\hline Q7 & 0.930 & 0.000 & 0.361 & Valid \\
\hline Q8 & 0.923 & 0.000 & 0.361 & Valid \\
\hline Q9 & 0.926 & 0.000 & 0.361 & Valid \\
\hline Q10 & 0.911 & 0.000 & 0.361 & Valid \\
\hline
\end{tabular}

From the preceding table, the total score of significance (2-tailed) from Q1 up to Q10 is (0.000), and the pearson correlation has a positive value because the score was higher than 0.361 it indicates that the questions are valid. Alpha Cronbach method through IBM SPSS Statistics 23 was used to analyze the reliability of the questionnaire. The basis for decisions in Alpha Cronbach reliability testing is: If the value of Alpha Cronbach $>0.60$ indicates the question or questionnaire is reliable. Whereas, if the value of Alpha Cronbach < 0.60 it indicates the question or questionnaire is not reliable. Based on the result of the analysis, the score can be summarized that the reliability questionnaire's total score was 0.978 , which was higher than 0.60. It indicates that the questionnaire was reliable.

\section{Normality Test}

The researcher used IBM SPSS Statistics 23 to measure the normality test, namely One-Sample Kolmogorov-Smirnov Test and Shapiro-Wilk. SPSS has a criterion in the normality test. If the significance value is higher than 0.05 , it indicates the data has a normal distribution. Conversely, if the significance value is less than 0.05 , it means the data is not normal. The table above indicates the significance (2-tailed) of Kolmogorov-Smirnov was $0.000<0.05$, which means that the data is not normally distributed, and the significance (2tailed) of Shapiro-Wilk was $0.000<0.05$, which mean that the data is not normally distributed. From the table above, it can be concluded that the data is not normally distributed, and the Paired-Sample T-Test cannot be applied in the data analysis technique. Combined with the previous sentence, one of the requirements to apply it, the data must be normally distributed. As an alternative, the researcher used non-parametric statistics to analyze the data, namely the Wilcoxon Signed Ranks Test, by using IBM SPSS Statistics 23 to find out the hypothesis data, whether any differences between the result of students' pre-test and post-test score.

\section{Data Analysis}

The result of the pre-test and post-test are analyzed by using the Wilcoxon Signed Ranks Test. The result of the questionnaire by using testing validity and reliability in IBM SPSS Statistics 23 to measure the effectiveness of Google Classroom to enhance students' writing performance. Based on the computational data, the values obtained showed negative ranks. It was (18), which indicates 18 students' value decreased from pre-test to post-test, (11) positive ranks that indicate 11 students' value increase from pre-test to post-test. The Mean rank was (10.14), whereas the sum of ranks was 111.50, and the ties were (1). This indicates that none of the students get the same value in the score of pre-test and post-test.

\section{Hypothesis Testing}

This research applied two kinds of hypotheses: (1) Null hypothesis $(\mathrm{Ho})$ mentions that there is no significant value of students' achievement on the writing recount text by using 
Google Classroom. (2) The alternative hypothesis $(\mathrm{Ha})$ mentions that there is a significant value of students' achievement on the writing recount text by using Google Classroom. From the previous table, it can be seen that the data of significance (2-tailed) was 0.022 . It indicates that the significance level lower than $0.05 \quad(0.022<0.05)$. It means that the alternative hypothesis $(\mathrm{Ha})$ was accepted, and the null hypothesis $(\mathrm{Ho})$ was rejected. This can be explained that there was a significant value of students' achievement on the writing recount text by using Google Classroom for tenth-grade students of Senior High School X in Surabaya. It showed that the use of Google Classroom was effective in teaching writing.

The data obtained from the questionnaire showed that the students' response is neutral. It means they respond to behave fairly balance in the use of Google Classroom. They did not feel any difficulties in the implementation of Google Classroom as the instructional medium in the teaching and learning process.

\section{Discussion}

\section{Effectiveness of Google Classroom}

Based on this study's results in the previous section, the table of Wilcoxon Signed Ranks Test statistics showed the significance level was 0.022 . As a hypothesis requirements, when the significance level smaller than significance (0.05), which indicates that the null hypothesis $(\mathrm{Ho})$ is rejected and the alternative hypothesis $(\mathrm{Ha})$ is accepted. In contrast, if the significance value is higher than (0.05), it indicates that the null hypothesis ( $\mathrm{Ho}$ ) is accepted, and the alternative hypothesis $\mathrm{Ha}$ ) is rejected. Based on the statement above, it can be inferred that the alternative hypothesis $(\mathrm{Ha})$ was accepted, while the null hypothesis $(\mathrm{Ho})$ was rejected based on the result of the significant value $0.022<0.05$.

This study's result was in line with Negara (2018) that Google Classroom is an online medium generated to help teachers or lecturers create a task, share teaching material, collect paperless assignments, assess student duty, and be attributed by automatic document storage. It can also be utilized as a media of interaction between students and teachers, arranging classes either in distance class or paperless tasks that can be held without being bound by space and time. On the other hand, Google Classroom did not affect the student's writing product with various limitations because this case was not a scope of Google Classroom to grow with, in terms of psychological area, to make them disciplined in every activity related to the academic assignment. In terms of discipline, many students were late in submitting the assignment, and eventually, they ignored the duty though it was attributed by notification of due date and time. As a result, there were several assignments given by the teacher not handed in. Factors, internal or external, might cause this.

The internal factors are caused by the lack of awareness from the students themselves. They did not care about that and get a lack of motivation to accomplish their assignment, while the researcher has warned to every single student through Google Classroom and WhatsApp Group. It is in line with Haerazi and Irawan (2019) who argue that motivation to learn affects students' writing exercises. In this study, various learning tools are used as a communication medium to facilitate communication with students. Then it is more accessible and closer to their daily lives. On the other hand, the students experienced difficulties and felt hard to buy internet data with an unlimited network because they did not have enough money while it was expensive for them. In addition, sometimes, they got an internet error to explore this occurrence caused by signal error or power failure.

In conclusion, the implementation of Google Classroom as a medium in teaching writing recount text has a significant effect on the students' writing product. In other words, Google Classroom also assists teachers and students in communicating the material and assignment between them. Furthermore, it might need more time, more effort, and more spirit for teachers and additional techniques to enhance students' writing ability. 
To investigate the students writing performance, the researcher used Brown (2003) writing performance theory. Brown (2003) explained that written performance is divided into four categories: imitative, intensive, responsive, and extensive. Based on the analysis, it was found that there 9 students got an imitative category. This means that their writing performance was in the basic category, which includes appropriate words, punctuation, and very brief sentences. Another finding that can be explained that there were ten students who got an intensive category. This indicates that the students' writing has produced an appropriate vocabulary, arranging the sentences into good paragraphs and correct grammatical features, and there were 11 students who did not submit assignments, so the researcher let their scores blank. This study found there were none of the students who got a responsive and extensive category. Based on the curriculum 13 (K13) Kemendikbud (2013), the tenth-grade students' writing performance should achieve the responsive level because the learners should show at the limited discourse level and arrange the sentence into a paragraph, and make a logically connected sequence of two paragraphs.

\section{CONCLUSION}

Based on the results and discussion of the study, it can be summarized that there was a significant value on students writing recount text by using Google Classroom for Tenth Grade students of Senior High School X in Surabaya. Learning outcomes of students score that shown by the result of Wilcoxon Signed Ranks Test the value of significance (2-tailed) was lower than the significant level $(0.022<0.05)$, then the $H a$ was accepted.

Furthermore, based on the result of a questionnaire, the students behave fairly balanced in responding to the implementation of Google Classroom. It means that the students did not have any difficulty in using Google Classroom. However, in this study, the students did not adapt well to the use of Google Classroom because they were usually late in submitting the assignment and ignoring it. It contributed to a few students who missed it. This can be recognized from the record of the post-test and several assignments delivered during the research. From this issue, it can be inferred that Google Classroom is effective as an instructional medium in the teaching of writing recount texts because it facilitates students to finish and collect the assignment without any bound by time and space.

\section{REFERENCES}

Alim, N., Linda, W., Gunawan, F., \& Saad, M. S. M. (2019). The Effectiveness of Google Classroom as An Instructional Media: A Case of State Islamic Institute of Kendari, Indonesia. Humanities \& Social Sciences Reviews, Vol 7, No 2, 2019, 7.

Ananda, R., \& Fadhli, M. (2018). Statistik Pendidikan (Teori dan Praktik dalam Pendidikan) (S. Saleh Ed.). Medan: CV. Widya Puspita.

Archibald, M. M., Ambagtsheer, R. C., Casey, M. G., \& Lawless, M. (2019). Using Zoom Videoconferencing for Qualitative Data Collection: Perceptions and Experiences of Researchers and Participants. SAGE, Volume 18: 1-8, 8.

Brown, H. D. (2003). Language Assessment- Principle and Classroom Practice: Pearson ESL.

Djaali, \& Muljono, P. (2014). Pengukuran dalam Bidang Pendidikan. Jakarta: PT. Grasindo

Genova M.M. (2019). Designing an effective digital learning environment for teaching English through literature: the learning experience of Bulgarian students, Journal of eLearning and Knowledge Society, 15 (2) DOI: https://doi.org/10.20368/1971$\underline{8829 / 1592}$

Harjanto, A. S., \& Sumarni, S. (2019). Teachers' Experiences on The Use of Google Classroom. 3rd English Language and Literature International Conference (ELLiC) Proceedings, Vol. 3, 2019, 7. 
Haerazi, H., Irawan, L. A., Suadiyatno, T., \& Hidayatullah, H. (2020). Triggering preservice teachers' writing skills through genre-based instructional model viewed from creativity. International Journal of Evaluation and Research in Education (IJERE), 9(1), 234-244 DOI: http://doi.org/10.11591/ijere.v9i1.20395

Haerazi, H., \& Irawan, L. A. (2019). Practicing genre-based language teaching model to improve students' achievement of writing skills. IJELTAL (Indonesian Journal of English Language Teaching and Applied Linguistics), 4(1), 9-18. http://dx.doi.org/10.21093/ijeltal.v4i1.246

Harmer, J. (2012). Essential Teacher Knowledge: Core Concepts in English Language Teaching. In: Pearson Longman.

Iftakhar, S. (2016). Google Classroom: What Works and How? Journal of Education and Social Sciences, Vol. 3, 7.

Jonhson, B., \& Christensen, L. (2016). Educational Research Quantitative, Qualitative, and Mixed Approaches (Sixth Edition ed.). United Kingdom: Sage Pablication Ltd.

Keržič D., Aristovnik A., Tomaževič N., Umek L. (2018), Evaluating the Impact of e-learning on Students` Perception of Acquired Competencies in a University Blended Learning Environment, Journal of e-Learning and Knowledge Society, 14(3), 65-76. DOI: https://doi.org/10.20368/1971-8829/1440

Kemendikbud. (2013). Kerangka Dasar dan Struktur Kurikulum Sekolah Menengah Atas/Madrasah Aliyah. Jakarta: Kemendikbud

Kurotun, S. (2015). Improving Students' Ability in Writing Descriptive Text by Using Picture. (Bachelor), Walisongo State Islamic University, Semarang.

Latief, M. A. (2015). Research Methods on Language Learning an Introduction. Malang: Universitas Negeri Malang.

McLean, S. (2011). Writing for Success: Flat World Knowledge.

Negara, I. M. (2018). Students Perception: The Use of Google Classroom In TeachingLearning Process Jurnal Ilmiah STBA, Vol.4 No.1 14.

Pappas, C. (2015). Google Classroom Review: Pros and Cons of Using Google Classroom in e-learning.

Wijaya, A. K. (2014). The Effect of Using Mind Mapping on the Writing Comprehension Ability of the Tenth Grade Students at SMA Tiga Maret Yogyakarta in the Academic Year of 2014/2015. (S1), Yogyakarta State University, Yogyakarta.

Wisdhawan, D., \& Kumalarini, T. (2014). Using Diary to Help Students of Eighth Grade to Write a Recount Text RETAIN, Vol 2, No 3. , 4. 